\title{
Synergetic Approach to the Formation of the Normalized Tempo-Rhythmical Organization of Speech in the Russian Language as a Foreign Language of Bilingual Children
}

\author{
Zinaida V. Polivara \\ Tyumen State University \\ Polivara.z@mail.ru
}

\section{Doi:10.5901/mjss.2015.v6n3s4p135}

\section{Abstract}

\begin{abstract}
Theoretical and applied aspects of bilingualism at present, more and more attract the attention of not only linguists, and researchers in the field of speech-language pathology. This interest is due to the relevance of the problem of bilingualism (multilingualism) in the world. Currently in places of compact residence of the Tatar population, in particular in the Tyumen region, is created an environment, conducive to the development of early bilingualism. Tatars are the second largest by population in the Tyumen region. Also there is a marked growth in the number of representatives of the Turkic ethnic groups (Azeris, Kazakhs, Kyrgyz, Uzbeks), due to migration processes. This raises the problem of learning Russian as a second language by children bilinguals who arrive with their parents. The new realities of the post-Soviet world has led to an increase of the distance in school programs, the reduction of the role and place of Russian language in the newly independent states, which creates additional difficulties in the adaptation of migrant children. It is important to realize that the choice of strategy of formation of the linguistic features of children with speech dysfunctions and bilingualism is not possible without recourse to physiological and neuropsychological mechanisms of speech, psycholinguistic aspects of language analysis.
\end{abstract}

Keywords: tempo-rhytmical organization, bilinguals, children, Russian language, foreign language.

\section{Introduction}

The behavior of the person corresponds to the values that are generated on the basis of norms, traditions, serving as a significant dominate in a certain ethnic group. These values are defined as cultural values. Therefore, the model of speech behavior of native speakers, the speed of writing and speaking is a major factor in the cultural space (Karabulatova \& Polivara, 2013; Dubkova, 2013 \& Konovalova \& Muradyan, 2014). In the assimilation of the Russian language in non-Russian audiences, especially, greater complexity is the learning of reading. As a rule, the Turks bilinguals of primary school age experience great discomfort in decoding of the letters of the Russian alphabet and in reading of Russian texts (Polivara, 2013) as Azerbaijan, Uzbekistan switched from Cyrillic to the Latin alphabet, to such a step volunteered also Kazakhstan. All this creates additional difficulties for learning the Russian language. To this you must also add the specifics of the Turkic mentality, which has significant differences from Slavic (Karabulatova, Koyche \& Gultyaev, 2013 \& Polivara \& Karabulatova, 2011), including the stereotyped understanding of the pace and speed of speech [Karabulatova, Polivara \& Zamaletdinov 2014 \& Polivara \& Karabulatova, 2014). To justify the relevance of the issues discussed in this article, we would like to cite a famous author V.N. Zaitsev from her work "Provisions of learning to read" [1991, 2001]: "Relying on the opinion of teachers, we selected more than 40 factors (out of 200, approx. ed.), impacting on academic performance; then more than two thousand students tested, questionnaired, tested and conducted. It turned out that there is the number one factor, which effect on performance is much stronger than the impact of all other factors. This factor number one is speed of reading" (Zaitsev, 1991).

Today, among the teachers there is a view that in light of the Federal educational standards of the second generation the main center at testing the technique of reading should be focused not on speed, but on the understanding of the text (Kruglova, 2009). In addition, individual sound is not the fact of language, as a fact of language, it become only as a member of a certain system in all ties and relationships. For bilinguals, the pronunciation of individual sounds of nonnative language becomes a difficult and lengthy process, which has a negative impact on tempo-rhythmical organization of speech in reading and speaking (Ortiz-Lira, 1999 \& Scandera \& Burleigh, 2011; Ashby, 2005; Patil \& Kentner et al, 2008; Féry \& Kentner 2010 \& Polivara, 2014).

The very understanding of the text in the elementary school provides a particular challenge for Turkic bilinguals of 
primary school age, as the family language is the native language (Azerbaijani, Kazakh, Tatar, Uzbek, etc.). However, sociologists have noted ethnic conglomerations in major cities of Russia (Moscow, Tyumen and etc.), which also contributes to the assimilation of Russian as a second language (Ryazantsev \& Yang Hongmei, 2010). In the Russian government believe that the problem is very important for Russia. Most vividly the danger of occurrence of such enclaves is manifested in the metropolitan area, especially where many foreign nationals live. In pure form they do not yet exist, but we can already speak of areas where migrants live especially tightly (In Russia will start the struggle with ethnic enclaves, http://kemsoch99.ucoz.ru/index/chtenie/0-61). As a result, we have spontaneously formed multicultural linguistic personality in which ethnolinguistically cultural codes with a predominance of "video clip" thinking are blended (Karabulatova, 2013, p. 795). Parents in most cases, strive to educate their children in specialized educational institutions with Russian and other languages (English, German, French, Arabic and etc.). At the same time inside family communication in native language is traditionally used. Thus, Russian language usually remains the language of interethnic communication. Hence, the child is bilingual from early childhood, occurs in the complicated language situation.

\section{Methods and Materials}

Etnopsycholanguagecorrectional approach to the process of assimilation of the texts of the Russian language of bilingual children of primary school age allows us to consider language as a component of cognition, to analyze linguistic phenomena as a way of cogitative activity, giving birth to knowledge and operating them, and this determines the understanding of the essence of the process of language knowledge, the explanation of linguistic phenomena, analysis of the meaning and significance of perception and processing of structures of language consciousness. The absorption of the rate of speech and of the texts in the Russian language by children bilinguals of primary school age as a kind of cognitive activity is the process of acquiring the language competence of the secondary language personality. We strongly believe the speed of reading and understanding the text are complementary and should not be considered one at the expense of another. The pace of reading is one of the few available to the teacher and the school psychologist of numeric objective, comparable and psycho-physiological characteristics that allow to estimate and predict not only the student's progress, but also the dynamics of his mental health.

\begin{tabular}{|c|c|c|c|}
\hline Comparison test & Second language & Foreign language & Adoptive language \\
\hline $\begin{array}{l}\text { The environment in which } \\
\text { takes place the process of } \\
\text { acquisition/ learning/ } \\
\text { language acquisition }\end{array}$ & $\begin{array}{l}\text { Natural language environment in } \\
\text { the conditions of bilingualism }\end{array}$ & $\begin{array}{l}\text { Outside of the country of the } \\
\text { studied language }\end{array}$ & Natural language environment \\
\hline $\begin{array}{l}\text { The nature of the process of } \\
\text { mastering the language }\end{array}$ & $\begin{array}{l}\text { Unmanaged (mastering) } \\
\text { Managed (study) Combined } \\
\text { (comprehension) }\end{array}$ & $\begin{array}{l}\text { Managed } \\
\text { (study) }\end{array}$ & Coordinated (mastering) \\
\hline $\begin{array}{l}\text { Language functions in the } \\
\text { society }\end{array}$ & $\begin{array}{l}\text { A means of socialization of the } \\
\text { personality. Means of } \\
\text { communication in everyday life }\end{array}$ & $\begin{array}{l}\text { An educational tool, a study tool. } \\
\text { The means of Communication in } \\
\text { the classroom }\end{array}$ & $\begin{array}{l}\text { A means of socialization of the personality. } \\
\text { Means of communication in everyday life. } \\
\text { Communication in the classroom }\end{array}$ \\
\hline motivation & $\begin{array}{l}\text { The motivation to use language } \\
\text { in everyday communication due } \\
\text { to the conditions of existence of } \\
\text { the language }\end{array}$ & $\begin{array}{l}\text { Motivated by the need to use } \\
\text { language in professional } \\
\text { communication. Weak motivation. } \\
\text { Complete lack of motivation }\end{array}$ & $\begin{array}{l}\text { High motivation to use language in everyday } \\
\text { communication and for educational purposes }\end{array}$ \\
\hline $\begin{array}{l}\text { Aspects of language } \\
\text { teaching/ language learning }\end{array}$ & $\begin{array}{l}\text { Pragmatic orientation is dictated } \\
\text { by the purpose of mastering or } \\
\text { learning }\end{array}$ & $\begin{array}{l}\text { The balance of the pragmatic and } \\
\text { educational aspects }\end{array}$ & $\begin{array}{l}\text { Pronounced pragmatic orientation in } \\
\text { combination with the active introduction of } \\
\text { educational and technical aspects }\end{array}$ \\
\hline
\end{tabular}

Why does at such obvious importance and necessity of application of this method in? teaching practice appear such opinion?

In many literary and Internet sources normative data of rate of reading, that are not consistent with each other are taking place. For example, one source claims that the speed of reading in the second grade at the end of the first semester should not be less than 25 , and at the end of the second half at least $40-50$ words per minute. Another source believes that these options should be at least 40-50 words per minute at the end of the first half and at least 55-60 words per minute at the end of the second half. Tougher unsatisfactory evaluation of the second source compliance assessment of "4" of the first source, which are correspondingly for the first half - 40-55 words per minute and for the second half - 5570 words per minute (Kruglova, 2009; Standards of speed reading, 2011; Reading techniques, 2011; Basheva, 2011; 
Network of creative teachers, 2011 \& Tridcatochka, 2011).

In our opinion these inconsistencies of standards arises primarily because of the lack of tools to accurately measure and standardize the parameters of speed reading. On the other hand from parents more and more often we hear the regret that in our computer age, the processing of data about the pace of reading by teacher is made in "the old fashioned way, manually", which requires time-consuming and error-fraught.

In context of solving of these questions, we developed, together with colleagues from Moscow, automated system for investigation of tempo (speed) reading in the elementary school (hereinafter automated system or program, Figure 3).

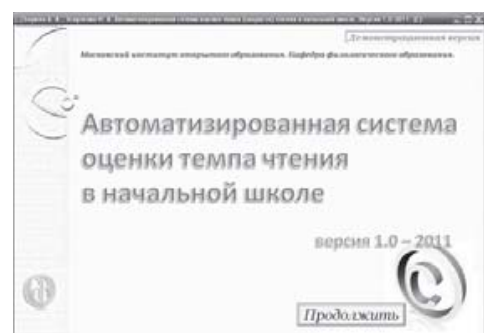

Figure 3. Automatized system for investigation of tempo (speed) reading in the elementary school

All the mentioned results are given in the material of their own research and are obtained using the aforementioned program. The automated system allows to keep, to process and to receive the results of reading of 30 different texts simultaneously for all classes of primary school (Figure 4). Inclusion of texts and lists of classes in the program, that is, its adaptation to specific school as usually does not cause complications for the teacher.

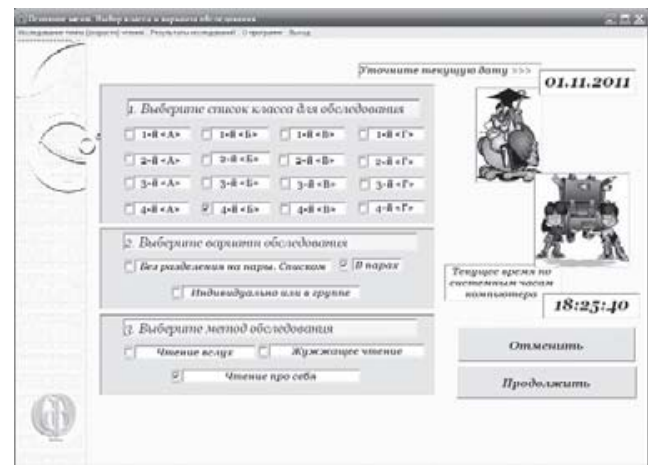

Figure 4. The main menu of the program: The selection of the mode of use of the program and method of the survey

Main menu of the programm, posted on the top line, allows to select two modes of its use for the study of the rate of reading or viewing the results of the research. The program at the discretion of the teacher allows to select the class option and the survey method. In the Fig. 4 is selected "4-b" class, version of the survey - "In pairs", the survey method "Read to yourself". After that, takes place the calculation of the present at the examination, as shown in Figure 5.

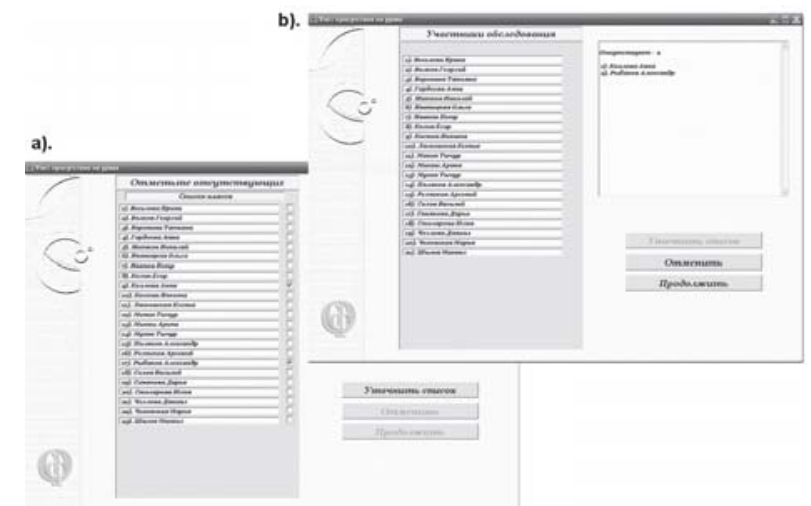

Figure 5. The form of calculation, presented at the examination: a) prior to the introduction of data missing; b) after the introduction about the missing 
If the teacher chose the survey in pairs (the second student reads the text from the place where he stopped the first student), the program allows in accordance with the placement of students in the class to divide them into pairs as shown in Figure 6.

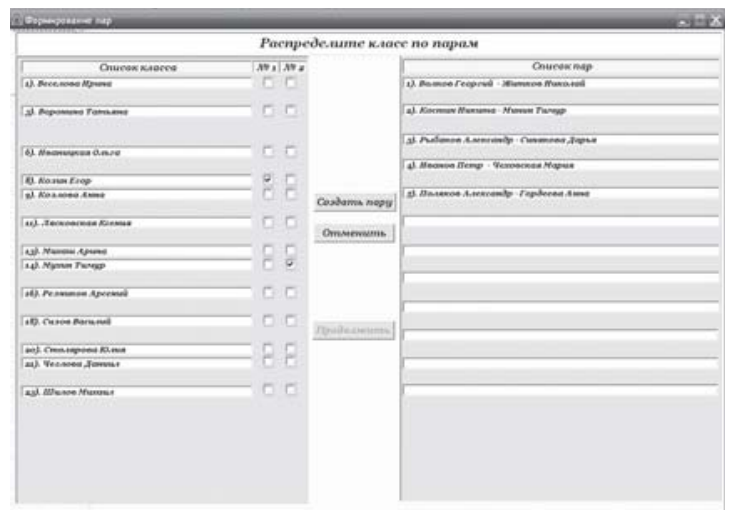

Figure 6. Couples allocation procedure.

The automated system provides the ability of distribution as one text for all students and individual text for each student, the name of the learner is placed in the upper window, as shown in Figure 7.

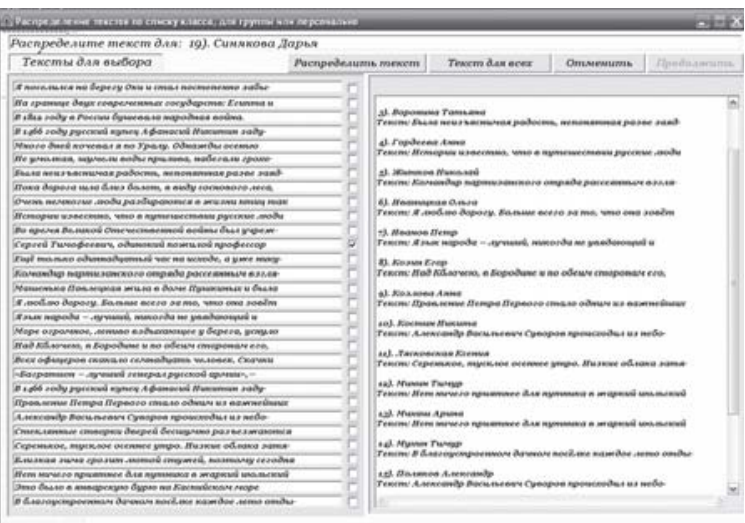

Figure 7. Text distribution procedure

After the distribution the children read the text to the teacher during the programmed time. The interval of this time is entered in minutes in the text box of the program, this form has also a timer, which is in the form of increasing bandwidth allows to track the task of completion time. At the end of the examination, the program gives audible and visual signals (Figure 8).

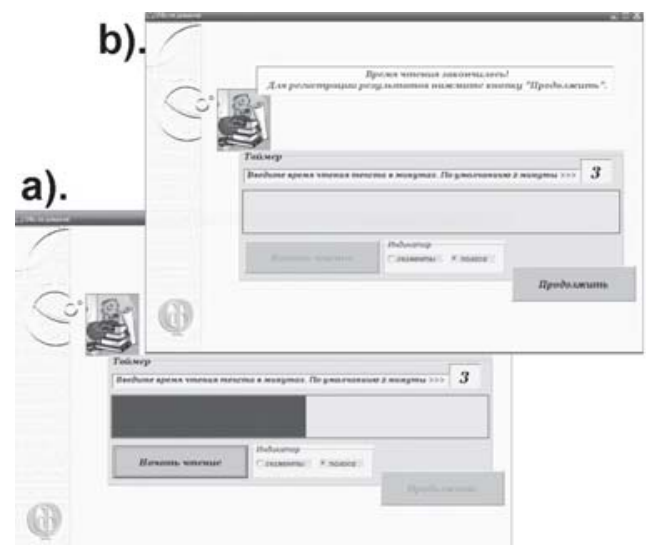

Figure 8. Measurement of reading time: a) - timer in the research process. It took one and a half minutes of the three established by the teacher; b) - the timer at the end of the study 
After the reading takes place the calculation, processing and saving of the results in the database (Figure 9).

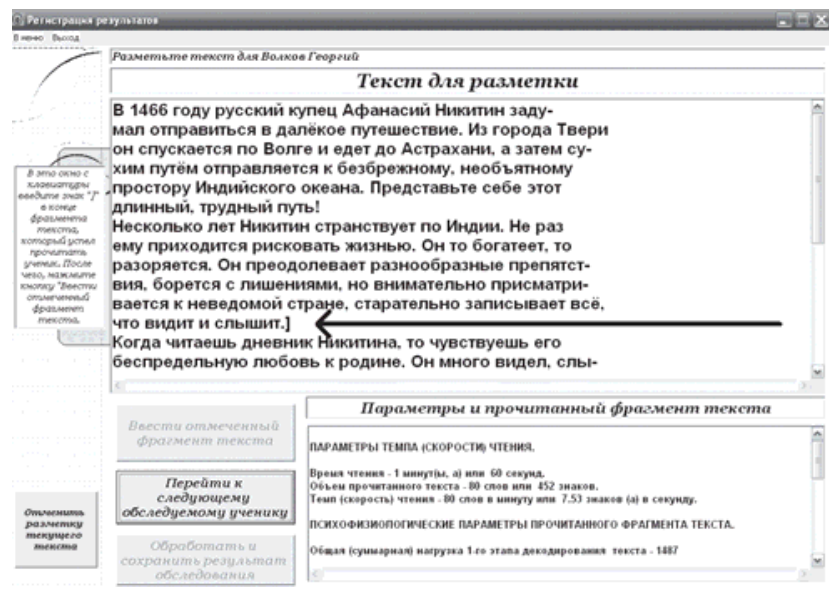

Figure 9. Accounting, processing and saving of the results of reading

In the upper window, shown in Figure 9 forms in list order or formed by teacher pairs appears the name of the student, and in the text box - the text that was assigned for this student. Using the sign "]" entered from the computer keyboard (in the figure this is shown by the arrow) the teacher marks the end of the text that had time to read the student, and clicks on the button "insert marked part of the text". After pressing this button in the lower window, fitted with scrollbars (scrolling), one receives the examination report, for example:

The parameters of the tempo (speed) of reading.

Reading time - 1 minute (s,) or 60 seconds.

The volume of reading text -80 words or 452 signs.

The tempo (speed) of reading 80 words per minute or 7.53 signs in a second.

Taking into account the relevance of the study question and its not sufficient elaboration, we had to answer the question "What are the characteristics of tempo-rhythmical organization of speech of bilinguals, and how bilingualism affects the predisposition to speech dysfunctions?" When developing theoretical and applied problems of bilingualism (Karabulatova, Polivara, Zamaletdinov, 2013; Polivara \& Karabulatova, 2011; Karabulatova, Koyshe \& Gultyaeev, 2013 \& Polivara, 2014) we proceeded from the idea of typologies of individual bilingualism: such psycholinguistic parameters as the degree of second language acquisition, the degree of autonomy of operation of the two language systems depending on the level of development of each language systems. The analysis of the materials, obtained in the process of traditional logopedic examination of children with bilingualism, was revealed heterogeneous level of proficiency in a second (Russian) language, with the full knowledge of their native non-Russian language in terms of age norm.

\section{Discussion}

Lets consider the well-known method of determining the rate of reading of L. A. Efrosinina (2010). It should be noted that the following material was not taken as a criticism of this distinguished author. Stated below data prove that L. A. Efrosinina conducted in a depth analysis and proposed a method, which without the use of automated means of data processing leads to the minimum error. In this regard, should appreciate this author thanked for his work. The development of automated means of computer processing of data that allows with less effort and with greater accuracy, reliability and clarity, as a rule, to be beyond the capabilities of a teacher

The essence of the method of L. A. Efrosinina is regardless of the reading method and the survey method, silently, out loud, buzzing reading, paired, individual reading, and etc., for 2-5 minutes, is counted the total number of words of test (text) readed by the student. For greater accuracy of calculations L. A. Efrosinina offers two options with the subsequent calculation of the final arithmetic mean value of the two values obtained for each of the options. The children themselves consider to read the words and letters. The space between words is counted as one letter.

According to the first variant on the basis of counting of the number of delivered words by the students is calculated the reading speed equal to the number of words per minute (reading speed $=$ number of read words for $2-5$ minutes/reading time in minutes (2-5 minutes)). According to the second variant on the basis of counting of the number of 
delivered letters by the student is calculated read speed equal to the number of words per minute (reading speed $=$ number of read letters for 2-5 minutes/6,4 (the average length of a word or DSS)/reading time in minutes (2-5 minutes)).

After the study with the personal card of verification of techniques of reading is filled, for example,

Ivanov Sasha, 2nd "A" grade

1. Reading aloud:

Words - 130 in 3'; 130: 3 = 43 words in 1';

Letters - 885 in 3'; 885: 3 = 295 letters in 1'; 295: 6,4 = 46 words in 1'.

Arithmetic average: (46+43): $2=44$ words in 1 '.

2. Reading silently:

Words - 165 in 3 '; $165: 3=55$ words in 1';

Letters - 1056 in 3'; 1056: $3=352$ letters in 1'; 352: 6,4 = 55 words in 1'.

Silently in 1 ' reads 55 words.

Why do not one, but two variants of the calculations and their subsequent averaging are offered?

From a methodological standpoint, there is a substantial probability of error when counting the number of words and in particular the number of letters in the text. As it is known in the practice of scientific research, all such calculations to avoid errors during the self-assessment should be repeated at least twice. It is obvious that is hard to carry out by elementary school students because of their age psychological characteristics and limited resources time. In this respect to the children for their motivation to the survey, are proposed two options of data processing, which add variety, support interest and eliminate the monotonous repetition of the same processing results.

From a statistical positions in the case of counting the number of read words by number of letters divided by the $\operatorname{OODD}(6,4)$, into statistics of method in advance is laid error. The magnitude of this error is illustrated by the data of our studies, carried out with the help of specially designed computer program presented in table. 1.

Table 1. Error count of the number of words in a random sample of texts recommended for study of rate of reading (Kruglov, 2010 \& Speech technology, 2011), using the ratio of the length of the middle word (OODD=6,4).

\begin{tabular}{|c|c|c|c|c|c|c|c|}
\hline \multirow[t]{2}{*}{ № } & \multirow[t]{2}{*}{ Version of the text } & \multicolumn{2}{|c|}{ Computer processing data } & \multicolumn{2}{|c|}{$\begin{array}{l}\text { The calculation using the } \\
\text { coefficient OODD with gaps }\end{array}$} & \multicolumn{2}{|c|}{$\begin{array}{l}\text { The calculation using the } \\
\text { coefficient OODD without gaps }\end{array}$} \\
\hline & & Letters without gaps & Words & Words & Error (\%) & Words & Error (\%) \\
\hline 1 & Badgers & 253 & 50 & 47 & 6 & 40 & 26 \\
\hline 2 & Spring & 285 & 46 & 52 & -11 & 45 & 3 \\
\hline 3 & Toucan & 303 & 62 & 57 & 9 & 47 & 31 \\
\hline 4 & Gold & 306 & 63 & 58 & 10 & 48 & 32 \\
\hline 5 & Competitions & 345 & 60 & 63 & -5 & 54 & 11 \\
\hline 6 & September & 348 & 62 & 64 & -3 & 54 & 14 \\
\hline 7 & In winter & 368 & 62 & 67 & -8 & 58 & 8 \\
\hline 8 & Wonderful tree & 419 & 86 & 79 & 9 & 65 & 31 \\
\hline 9 & Wind & 481 & 103 & 91 & 13 & 75 & 37 \\
\hline 10 & Obliging & 489 & 106 & 93 & 14 & 76 & 39 \\
\hline 11 & Grandfather & 571 & 139 & 111 & 25 & 89 & 56 \\
\hline 12 & Two mice & 688 & 138 & 129 & 7 & 108 & 28 \\
\hline 13 & Duty & 756 & 155 & 142 & 9 & 118 & 31 \\
\hline 14 & Who is the host? & 1251 & 283 & 240 & 18 & 195 & 45 \\
\hline 15 & Solomonov' trial & 1749 & 363 & 330 & 10 & 273 & 33 \\
\hline & & Mean error (\%) & & & $+12 \% ;-7 \%$ & - & $+28 \%$ \\
\hline
\end{tabular}

The texts are placed in the table in ascending order of their length or volume in the letters. According to the presented data, in the cases of counting the number of words using the coefficient OODD with gaps on this random sampling the error can reach up to $25 \%$, and excluding spaces to $56 \%$. Accordingly, the average error will be $12 \%$ and $-7 \%$ in the former and $28 \%$ in the second case. The error in the calculations using the gaps is much smaller. Thus, the recommendation of $L$. A. Efrosinina on account of the number of gaps when counting the letters of the read text is justified, as in this case, achieves a more accurate result.

Visual assessment of data, shown in table 1 does not give grounds to assert that increasing the amount of text increases the size of the considered errors. But in this case texts are shown. In the study of pace of reading by the pupils, as a rule, one text is offered that is methodologically justified from the standpoint of "purity" or equal for all participants of 
the study conditions. In this case are counted different length fragments of the same text. In Figure 1 are shown significant functional regularities of the dependence of the above errors on the volume of fragments of one read first text.

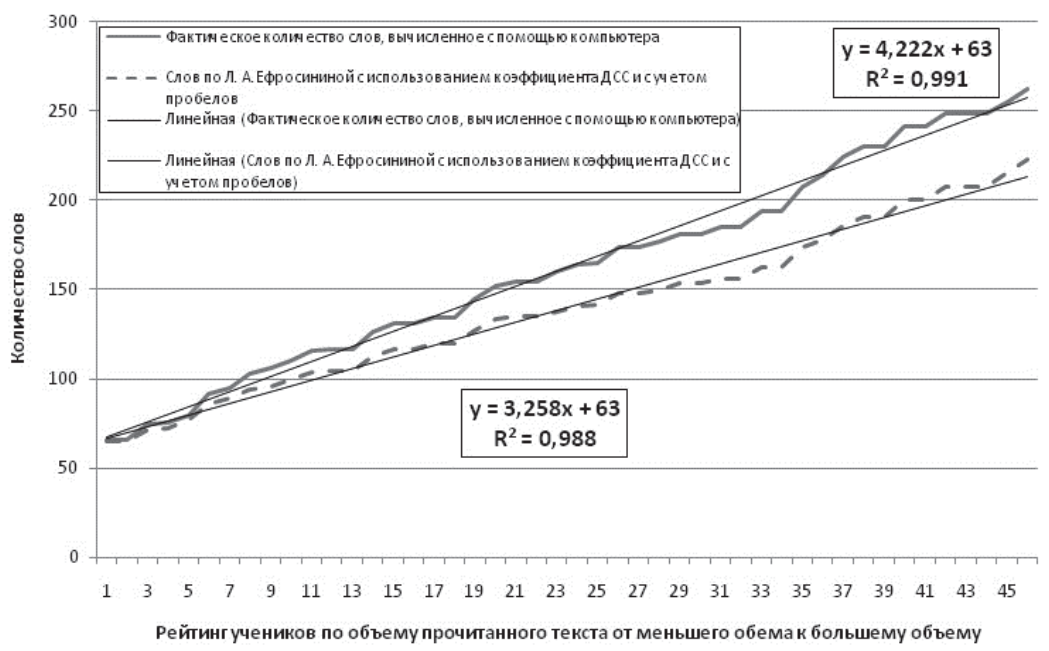

Figure 1. The dependence of the error in counting the number of words of read text with the use of the coefficient OODD from volume read first fragments of the same text

These data were obtained on the basis of an analysis of the students speed of reading of two second forms (46 people), held in October, 2011. The actual number of words read aloud for 2 minutes with a computer processing were in the range of 66 to 262 words, while with L. A. Yefrosinina's method - from 65 to 223 words. For the research the text V. Bianki "Peak the Baby Mouse", its first chapter, "How the Baby Mouse Became the Sailor" was used. The text was read first. For statistical analysis the results obtained during the study were sorted (ranked) from the smaller to the larger amount.

Based on the data shown in Figure 1 is not difficult to calculate the amount of error, which is equal to $30 \%((4,222$ * $x) /(3,258 * x)=1,296 ; 1,296 * 100-100 \approx 30 \%)$. Moreover, this inaccuracy will grow in direct proportion, together with the amount of text read that underestimates the result of the study not in favor of the student.

To avoid such a blunder the technique studied offers the calculation of the arithmetic mean of the two options of data processing (see above). Let's refer to Figure 2, which shows the reliable functional dependence of the inaccuracy of averaged final results of the methodic, calculated on the basis of studies of the same two second forms.

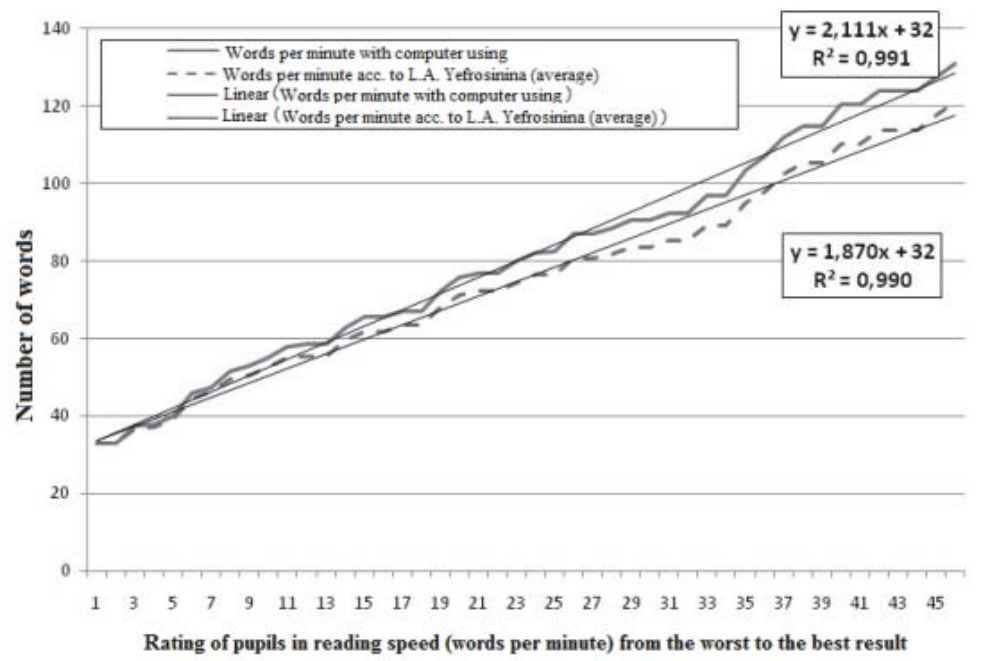

Figure 2. The inaccuracy of research results of reading speed obtained by the method of L.A. Yefrosinina 
Based on the data shown in Figure 2 one can see that the error quantity has decreased more than doubled from $30 \%$ to $13 \%((2,111 * x) /(1,870 * x)=1,129 ; 1,129 * 100-100 \approx 13 \%)$. This error is also directly proportional and grows with the amount of text read and lowers the result of the studies not in favor of the student.

In the practical comparing of the results of our researches in second forms it appears that of the 46 students evaluated by the existing criteria (<25 words per minute - "2"; 25-39 - "3"; 40-55 - "4";> 55 - " 5 ") as a result of this error, 4 students must be scored below. That is, it is $9 \%$ of all students passed examinations (4/46* $100=8,695 \approx 9 \%)$. Statistical data obtained show that, for any number of such observations, this value will be in the range of $5-13 \% \%$. That is, for the parallel classes (4 classes with 25 people in each, about 100 students), the number of students who will be put deliberately underestimated by the results of the survey will be from 5 to 13 people. In four parallel of elementary school (grades 1-4, about 400 people) - from 20 to 52 people. As a result of 16 studies for a year carried out with a periodicity of 1 times in a quarter, this figure for the initial class of each individual school may be between 320 to 832 people.

Thus, there is an urgent need to introduce automation tools in practice of speed reading examination in elementary school. To justify the psychophysiological position with respect to the subject let's turn to Table 2.

Table 2. The average length of words randomly selected texts (Kruglova, 2010 \& Speech appliances, 2011) recommended for reading speed studies in letters

\begin{tabular}{cc}
\hline Text & The average length of words in the text in letters \\
\hline Two Mice & 4,1 \\
\hline Duty & 4,42 \\
\hline Wind & 4,61 \\
\hline Obliging & 4,66 \\
\hline The Court of Solomon & 4,81 \\
\hline Toucan & 4,85 \\
\hline In Winter & 4,87 \\
\hline Who's the master? & 4,87 \\
\hline Competitions & 4,88 \\
\hline Grandpa & 4,98 \\
\hline Badgers & 5,06 \\
\hline A Wonderful Fur-tree & 5,61 \\
\hline Spring & 5,75 \\
\hline September & 5,93 \\
\hline Golden Snowdrop & 6,19 \\
\hline
\end{tabular}

The following table shows the ranked parameters of average word length in letters that were received as a result of a computer word processing. These texts are recommended for reading speed examination. As it seen from the table, none of the texts reach the average word length, which corresponds to the CRS index which is equal to 6,4. This is due to the fact that children are offered more simple texts, rather than the average text. Moreover, these texts have significant differences in average indexes between them, which reach 50\% $(6.19 / 4.10 * 100-100=50.9 \%)$.

In our earlier papers we have repeatedly stayed at the existing laws of the nervous system functioning in the process of perception of oral or written texts and on the fact that the quality of a student work with the text is very dependent on the structure of the text itself. If the frequency of occurrence of individual letters in the text or the length of its words, which are calculated in special programs, more than the usual evolutionary framework, the success of the student's work with the text greatly reduced. In particular we prove that when writing dictations on heavy texts (in physiological point of view) first form pupils make 2 times more errors, the fourth grade students - 1.3 times, and fifth and ninth grade students - 1.2 times (Polivara, 2014; Karabulatova \& Polivara, 2013 \& Polivara \& Karabulatova, 2011, p. 2, 47). These data correlate with the results obtained by our colleagues in Moscow (Birkin, 2007; Birkin, 2009). In the course of consideration of these items let's turn to Table 3. 
Table 3. Average load the first stage of decoding (letter formation) of a random sample of texts (Kruglova, 2010 \& Speech appliances, 2011) recommended for reading speed examination in letters

\begin{tabular}{|c|c|}
\hline Text & Average load of the first stage of decoding. \\
\hline The Court of Solomon. & 23 \\
\hline September. & 31 \\
\hline Duty. & 33 \\
\hline Grandpa. & 41 \\
\hline Who's the master? & 50 \\
\hline Wind. & 57 \\
\hline Spring. & 62 \\
\hline Two Mice. & 63 \\
\hline Wonderful Fur-tree & 63 \\
\hline In Winter. & 71 \\
\hline Obliging. & 73 \\
\hline Toucan. & 79 \\
\hline Badgers. & 83 \\
\hline Golden Snowdrop. & 109 \\
\hline Competitions. & 117 \\
\hline
\end{tabular}

This table shows the ranked parameters of average load of first stage of decoding (letter formation), which were obtained by computer processing of the same texts. As it can be seen from the table the texts have significant average differences between them that reach five times difference of parameters polar in loadings of texts decoding $(117 / 23=5.08)$.

\section{Results}

It is obvious, that the decoding parameters greatly affect the indices of reading speed. To what extent? We believe that we will be able to answer this question in the near future, as we study these relationships is ongoing. To justify the need for scientific development of outlined approaches, let's consider the data in Table 4.

Table 4. Indices of loadings of decoding of a random sample of texts (Kruglova, 2010 \& Speech appliances, 2011) recommended for reading speed examination in various grades of elementary school

\begin{tabular}{ccc}
\hline Text & Text is recommended for: & Indices of loading: \\
\hline Grandpa. & $2^{\text {nd }}$ form & 331 \\
\hline Obliging. & $2^{\text {nd }}$ form & 672 \\
\hline Duty. & $3^{\text {rd }}$ form & 337 \\
\hline Two mice. & $3^{\text {rd }}$ form & 422 \\
\hline The Court of Solomon. & $4^{\text {th }}$ form & 557 \\
\hline Who's the master? & $4^{\text {th }}$ form & 346 \\
\hline
\end{tabular}

The table shows the integral indices of texts loading that take into account both the first (letter formation) and the second (derivation) decoding steps loadings. As before, these parameters were obtained by computer processing. As it is seen from the table the texts "obliging" "Two mice" and "The Court of Solomon" in their physiological parameters are not suitable as for test task for reading speed examination as in the process of their reading the reading speed will decline independent from the child physiological reasons.

The stated approach to the reading speed examination is belonged to the sphere of knowledge and skills of professional psychological selection. Theory and practice of this trend in various government departments having been perfected over decades and is developed enough. In the course of this development the validity and reliability of the techniques were of paramount importance. Currently, professional psychological possess sufficiently reliable mathematical tools and experience allowing to carry out standardization of data under consideration.

While using this experience and common sense, one should raise the question: "Why with such serious discrepancies (see Table 1, 2 above and drawings) teachers still continue traditionally use the number of words read per minute by a child as an indicator characterizing the reading speed? While the use of speed reading in letters (signs), read per minute or per second, a priori removes many of the problems discussed?". 
On the other hand the realization of that requires the use of automated information processing tools that eliminate errors and greatly facilitate the work of teachers, reducing the time it takes them to process the data. In the case of solving this problem, we obtain accurate and objective dynamic performance of the state of the nervous system of the child, which will be of interest not only for school teachers, psychologists, linguists, psychologists, but also for physicians.

Obviously, the physiological parameters of the text read closely related to the overall development of the child as well so to the peculiarities of bilingual language personality (Polivara, 2014).

Total load of the 1st stage of text decoding - 1487

The average load of the 1st stage of text decoding - 41

The average load of the 2 nd stage of text decoding (word length) - 5.65

Text perception index - 223

The length of the text in standard seconds - 37.6

Thus, in the protocol the text about Athanasius Nikitin's three seas walking is taken. The text, which the pupil was managed to read in the regulated time, is following:

In 1466 the Russian merchant Athanasius Nikitin planned to go on a long journey. From the city of Tver he goes down the Volga and then to Astrakhan, and then by land goes to the boundless, vast expanses of the Indian Ocean. Imagine the long, hard way! Several years Nikitin wanders India. More than once he had to risk his lives. He gets richer, than it ruins. He overcomes various obstacles, struggles with hardships, but carefully eyes the unknown country, diligently records everything he sees and hears.

If teacher desires this protocol can be copied separately with the help of the context menu (right mouse button) through the computer's clipboard.

After clicking on "Go to the next examinee student" in the upper field appears a student next to the list of classes or pairs and the procedure is repeated. After the data of the list of the last pupil or pair input completion the button "Process and save the examination results" becomes accessible with which the results of the examination are recorded in a different file or in a database.

In the case of an examination in pairs for the second pupil in a pair who continues to read the text from the point where the first pupil it left off, the program for layout displays the text not from the very beginning but only remaining fragment, which significantly reduces the text markup. In addition, at the discretion of the teacher reading parameters can be recorded in the database not only during the examination, but also from paper according to the marks made by pupils or by the teacher in the examination process. Typically, in this case, the time of inputting and processing of reading results of 23-25 studentstakes 10-15 minutes.

In playback mode of the results of examination the program allows quickly to rate and compare their dynamics. Figure 10 shows the procedure for such a rate.

With the help of unfolding lists at the top of upper part of the form a class and a pupil is selected. After selecting a pupil from the list of class the program processes and quickly displays the accumulated information on it. In the left window in the form examination protocols is displayed in textual variants, which also can be copied through the computer clipboard; and in the right windows bar graphs illustrating the dynamics of the results of an examination of the reading speed in words per minute and in letters (signs) per second are displayed. These data clearly correlate with the average indices for the class (parallel) and with the minimum acceptable benchmark of reading speed for an adult.

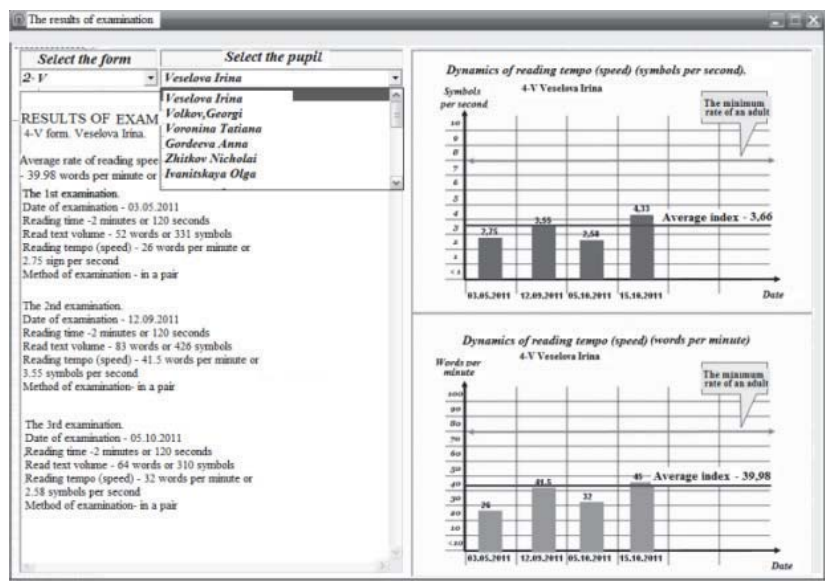

Figure 10. The form of examination results representation 
Table 5 shows the fragment of the reduced (without physiological parameters) version of the report on the examination generated in Word editor with the help of this program.

Table 5. The variant of report on examination obtained by using a text editor Word

\begin{tabular}{|c|c|c|c|c|c|c|c|c|c|}
\hline \multirow{2}{*}{ Form } & \multirow{2}{*}{$\begin{array}{c}\text { Surname } \\
\text { Name }\end{array}$} & \multirow{2}{*}{$\begin{array}{c}\text { Date of } \\
\text { Exam }\end{array}$} & \multicolumn{2}{|c|}{ Duration of reading } & \multicolumn{2}{|c|}{ Volume of the read text } & \multicolumn{2}{|c|}{ Reading tempo (speed) } & \multirow{2}{*}{ - Method } \\
\hline & & & Minutes & Seconds & Words read & Symbols read & Words per minute & Symbols per seconds & \\
\hline $2-G$ & Kuzin & 22.10 .2011 & 2 & 120 & 207 & 905 & 103,5 & 7,54 & $\mathrm{P}, \mathrm{al}$ \\
\hline $2-G$ & Petrova & 22.10 .2011 & 2 & 120 & 152 & 701 & 76 & 5,84 & $\mathrm{P}, \mathrm{al}$ \\
\hline $2-G$ & Ryabov & 22.10 .2011 & 2 & 120 & 134 & 632 & 67 & 5,26 & $\mathrm{P}, \mathrm{al}$ \\
\hline$\ldots$ & $\ldots$ & $\ldots$ & $\ldots$ & $\ldots$ & $\ldots$ & $\ldots$ & $\ldots$ & $\ldots$ & $\ldots$ \\
\hline
\end{tabular}

In our experience, for a teacher, who has basic computer skills, 40-45 minutes is enough to learn practical skills for this automated system using. In the course of its development, we tried to consider all the possible errors. In this regard, our software is equipped with a powerful set of algorithms that allows in "user - program - user" interactive mode to keep practicing teachers from data loss and to train him to use the technology optimally.

In the context of considering automated system improving it should be made clear that the introduction of the program algorithms that calculate the mark of the student on a five-point scale adopted, we considered to be inappropriate. We believe that the final assessment of the abilities of the child should still be leaved for a teacher. Therefore, our software is aimed primarily at providing to a teacher an objective, reliable, visual, numerical and comparable data, as well as his personal savings of time and effort.

Conclusion. We are currently developing a module of the program, which will help to evaluate not only the understanding of the text, but also the expressiveness of its reading. These criteria are also very dependent on the physiological parameters of the text (Karabulatova, 2008 \& Living Tradition of Siberia Incantation, 2010). In the long term with sufficient interest of practicing teachers, we plan to find the valid and reliable integrated indicators characterizing the technique of reading in general. In conclusion we would like to mark out on the value of this method for secondary schools, for which will quote V.N. Zaitsev again:

"We came in one of the schools and asked for 6-8 grades registers. We have written down the names of the Astudents in one list, then the names of B-students in another list, and compiled a list of the remaining C-students. Ask for archive registers for past years, when these students were the third grade students, the register in which the reading speed of these students was recorded. What it turned out? Those who became an A-student, at the end of third grade had 130-170 words per minute reading speed. The average is about 150 words per minute. Those who in grades 6-8 became B-student had at the end of grade 3 from 100 to 140 words per minute reading speed. The average is about 120 words per minute. C-students had read speed of 80-90 words per minute (approximately, of course). This is the law.

Let's write it out:

«5»- 150

$\ll 4 »-120$

«3»- 90

This pattern cannot be neglected and must be taken into account in our work" [Zaitsev, 1991]. So, all bilingual children with normal speech ontogeny were assigned to three different variants of bilingualism, depending on the degree of ownership of a second language (Russian): I variant (coordinative bilingualism) were defined as children with so-called "early bilingualism", which had shown speech fluency in both languages (when freely switch from one language to another was done). To the II variant (subordinative bilingualism) children with early bilingualism, who observed a sufficient level of speech and the Tatar and Russian languages were referred. However, it was characterized by the presence of interference errors on phonetic, lexical-semantic and grammatical levels in Russian. To the variant III (interference bilingualism) refers children with an average bilingualism (beginning to learn the language after 5 years), whose level of Tatar speech corresponded to age norm, while Russian speech was accompanied by significant difficulties. Children Russian speech experienced the strong influence of the grammatical system of the native language; that is reflected in the specific error (attrictions) due to the presence of interlingual interference. They can be characterized as speakers with elements of secondary language system with an unfinished language adaptation.

Thus, polycommunicative-ethnocognitive activity in Russian foreign language for bilingual children - is an active, conscious activity of the secondary language personality, aimed at creating a conceptual system of the target language in the structure of communicative competence in order to materialize the entire system of individual knowledge of secondary language personality and to acquire new knowledge by means of assimilated Russian. 


\section{References}

Birkin, A.A. (2007). Speech Code. St. Petersburg, Hippocrates. pp. 407.

Birkin, A.A. (2009). Nature of Speech. Moscow, Likbez. pp. 384.

Efrosinina, L.A. (2010). Literary Reading: Grade 2: Manual, 3rd ed., imp. Moscow, Ventana-Gaf. pp. 208.

Zaitsev, V.N. (1991). Resources for Read Teaching. Book for teachers. Moscow, Prosveschenie. pp. 33.

Kruglova, T.A. (2009). Monitoring and Verification Work in Reading for the 2 Term. In the: Elementary School, \# 21.

Standards of Reading Speed. Municipal Educational Institution Secondary School №99, 23.10.2011, http://kemsoch99.ucoz.ru/index /chtenie/0-61.

Reading Technique. For the Parents of the Future First-Grader, 28.10.2011, http://proveryashka.narod.ru/sovet2.htm.

Bazueva, E.N. (2011). Site of Primary School Teachers of Bazueva N.N., 29.10.2011 http://baznatnik.ucoz.ru/load/normativy_skorosti_ chtenija/10-1-0-67.

Network of Creative Teachers, 29.10.2011, http://www.it-n.ru/board.aspx?cat_no=5025\&tmpl=thread\&Boardld=48313\&Threadld= 1862 48

Tridtsatochka (Gymnasium № 30, Kurgan. The lower classes) 28.10.2011, http://tridcato4ka.u4uslegko.ru/index.php?option=com_ content\&view=article\&id=102:2011-04-19-16-40-25.

ProShkolu.ru. Web-portal, 23.10.2011, http://www.proshkolu.ru/user/Swetlaja/file/1145248

Dubkova, O.V. (2013). Influence of interlingual interference on bilinguals writing (based on the works of chinese russianists). In the interexpo geo-siberia. №2, V.6.

Karabulatova, I.S. \& Polivara Z.V. (2013). Turkic and Slavs: Bi-polylinguism in Globalization and Migrations (on an example of Tumen region). Middle-East Journal of Scientific Research 17 (6): 832-836.

Karabulatova, I.S., Koyche K.K. \& Gultyaev V.N. (2013). The Dialogue of Kazakh Steppe and Russian Forest: About the Character of Turkic-Speaking Linguistic Personality on the Territory of Russian-Kazakhstani Border-Zone // Middle-East Journal of Scientific Research 17 (7): 853-858.

Karabulatova, I.S, Polivara Z.V. \& Zamaletdinov R.R. (2013). Ethno-Linguistic Peculiarities of Semantic Perception of Language Competence of Tatar Bilingual Children// World Applied Sciences Journal Issue 27 (Education, law, economics, language and communication): 141-145.

Polivara, Z.V. \& Karabulatova I.S. (2011). Linguistic Personality in a Transformed Community: Ethno-Linguistic Differentiation of Bilingual Tatars in Inethnic Bilingual Environment. Ed. by I.S.Karabulatova. Collect. Monograph. Tyumen: Pechatnik, pp. 146.

Konovalova, N.I. \& Mouradian D.G. (2014). Interlingual Interference in Bilingual Speech and its Experimental Study. In the: Teacher Education in Russia, №5.

Punegova, G.V. (2012). Particularities of the pronunciation of affricates in a foster bilinguals speech (on the basis of experimentallyphonetic research under russian-komi bilingualism) herald of chelyabinsk state university № 21 (275).

Scandera, P., Burleigh P. (2011). A Manual of English Phonetics and Phonology. 2 ed. Mössingen, CompArt, pp. 169.

Ashby, P. (2005) Speech Sounds. Routledgel Taylor\&Francis. pp. 120.

Ortiz-Lira, H. (1999). Word Stress and Sentence Accent. Blackpool. 1999. pp. 81.

Caroline, Féry \& Gerrit Kentner (2010). The Prosody of Embedded Coordinations in German and Hindi.

Patil, U., Kentner G., Gollrad A., Kügler F., Féry C. \& Vasishth S.(2008). Focus, word order and intonation in Hindi, Journal of South Asian Linguistics 1, pp. 55-72.

Russia Will Fight Ethnic Enclaves, Online Source http://finrussia.ru/news/show/etnicheskie-anklavi-131015001.

Gordon, M. \& Applebaum A. (2006). Phonetic Structures of Turkish Kabardian. Journal of the International Phonetic Association. 11/2006; 36(02): pp. 159 - 186.

Polivara, Z.V. (2013). Linguistic Analysis of the Difficulties of Mastering the Syllabic Structure of the Word by Bilingual Children. In the: European Journal of Social Sciences. International Journal of European Social Science Journal. Riga-Moscow, 4(32) Vol. 1, pp.46-250.

Polivara, Z.V. (2014). Psycholinguistic aspects of the impact of bilingualism on the assimilation of tempo-rhytmic organization of speech of preschool children bilinguals of tatar nationality. In the: European Journal of Social Sciences. International Journal of European Social Science Journal. №2-1 (41), pp. 155-158.

Polivara, Z.V. (2014). Psychophisiological Mechanisms of Linguistic Modeling of The World Structure in the Children-bilinguals with Speech Dysfunctions. In the: Advances in Environmental Biology. \#8(10) June, pp. 508-512.

Ryazantsev, S.V. \& Yang Hongmei (2010). Chinese migration in Russia: trends, consequences and approaches to regulation. Moscow: Publishing House "Eco-Inform", pp. 147. 